\title{
Genetics of susceptibility to tuberculosis in humans
}

\author{
M.J. Newport1, S. Nejentsev²
}

ABSTRACT: Genetics of susceptibility to tuberculosis in humans. M.J. Newport, S. Nejentsev.

There is substantial epidemiological evidence that host genetic factors in part determine susceptibility to mycobacteria, and many approaches have been applied to identify the specific genes involved. These include the study of single genes in 'knockout' mouse models and rare human families in which increased susceptibility to mycobacterial infection segregates as a single gene defect. Several genes have now been studied in many different populations. This review gives an overview of the progress made in the field of genetic susceptibility to tuberculosis and highlights more generally some of the challenges involved in the identification of complex disease genes.

Monaldi Arch Chest Dis 2004; 61: 2, 102-111.

Keywords: Tuberculosis, gene, association, linkage, HLA, NRAMP1, IFN- $\gamma, I L-12$.

${ }^{1}$ Brighton and Sussex Medical School, University of Sussex, Brighton, UK ${ }^{2}$ JDRF/WT Diabetes and Inflammation Laboratory, Cambridge Institute for Medical Research, University of Cambridge, UK.

Correspondence: Dr Melanie Newport, Brighton and Sussex Medical School, University of Sussex, Falmes, Brighton, BNI 9PX, UK, e-mail:n.j.newport@bsms.ac.uk

\section{Introduction}

\section{Overview}

It is estimated that 8 million individuals develop TB annually, and 3 million die as a result of their disease [1]. Thus Mycobacterium tuberculosis (MTB) is one of the leading infectious causes of death worldwide. However, these numbers represent a small proportion of the 2 billion individuals estimated to be infected with MTB - the majority develop an appropriate immune response and control infection without the development of clinical disease. Understanding the factors that distinguish these resistant individuals from susceptible individuals who develop disease has important implications for the development of new vaccines and therapies given that the vaccine BCG is not effective in many countries where TB is endemic [2], and multidrug resistant strains are emerging at an alarming rate [3].

What is the role of host genetic variation in susceptibility to TB?

Human immune response genes are more diverse than any other gene group, suggesting that infectious diseases are an important force in human evolution. The risk of dying from an infectious disease is increased 6 fold if a biological parent dies from infection before the age of 50 [4]. In this study the magnitude of the genetic contribution to infectious disease exceeded that or cancer or coronary heart disease. Analysis of familial clustering of infection [5] also suggests that genes are important determinants of susceptibility to infection, but families of course share more than their genes. There are also differences in disease susceptibility patterns, of clinical disease, and immune responses following infection with MTB between populations that correlate with the population's history of exposure to the infectious pathogen [6-9]. Twin studies demonstrating higher concordance rates in monozygous twins than in dizygous twins also provide strong support that host genetic variation determines susceptibility to TB $[10,11]$.

\section{Identification of TB susceptibility genes}

From a genetic point of view, TB is a complex disease resulting from the interaction between the host, the pathogen (which has a genome too) and the environment. The fact that the major aetiological factor MTB is known, unlike for many other complex diseases, allows insight in this complex interaction and eventually will help to clarify the functional role of the host factors. It is likely that a number of human genes affect susceptibility, but it is not known exactly how many or the relative contribution each makes. Despite the difficulties this presents a number of susceptibility genes have now been identified using several different but complimentary approaches.

\section{1) Animal models}

Studying animal models of disease susceptibility provides several advantages for genetic studies, including the ability to control breeding. Advances 
in immunology and molecular genetics have favoured the mouse model. There is much similarity in the basic immune response between mice and men, although there are differences as well, particularly in the immunopathology of the cellular response to MTB and in the function of some elements of the immune system, e.g. CD1 molecules [12]. The role of a particular gene in immunity to mycobacterial infection can be demonstrated using the technique of targeted gene disruption [13] to create "knock-out" mice. Genes to be targeted are chosen on the basis of what is understood about the immune response to mycobacteria and the mice challenged with mycobacterial infection. Table 1 lists some murine genes which appear to be important in mycobacterial immunity. A similar approach has been used to demonstrate the redundancy of other genes: mice lacking interleukin-4 (IL-4), IL-5, IL-10, or perforin as a result of gene disruptions were no more susceptible to mycobacterial infection than control mice $[14,15]$. Given the homology between the mouse and human genomes, genes identified as putative candidate genes in murine models can then be investigated in human populations. However, MTB is not a natural pathogen in mice and its immune system differs from the human in various aspects $[12,16]$.

Table 1. - Murine molecules, associated with susceptibility to mycobacteria in gene knockout experiments

\begin{tabular}{|c|c|c|}
\hline Molecule & Increased susceptibility to: & Reference \\
\hline Slc11a-1 (Nramp-1) & M. bovis (BCG) & [17] \\
\hline TNF $\alpha$ / TNF receptor & M. bovis (BCG) & {$[18]$} \\
\hline Interferon- $\gamma$ & M. tuberculosis & $\begin{array}{l}{[19]} \\
{[20]}\end{array}$ \\
\hline Interferon- $\gamma$ receptor 1 & M. bovis (BCG) & {$[21]$} \\
\hline$\beta 2$-microglobulin & M. tuberculosis/M. bovis (BCG) & $\begin{array}{l}{[22]} \\
{[23]}\end{array}$ \\
\hline MHC class II & M. bovis (BCG) & [23] \\
\hline $\mathrm{T}$ cell receptor & M. bovis (BCG) & {$[24]$} \\
\hline Interferon regulatory factor 1 & M. bovis (BCG) & {$[25]$} \\
\hline Interleukin-6 & M. tuberculosis & {$[26]$} \\
\hline Interleukin-12 & M. tuberculosis & [27] \\
\hline Inducible nitric oxide synthase & M. tuberculosis & {$[28]$} \\
\hline Toll-like receptor 4 & M. tuberculosis & [29] \\
\hline
\end{tabular}

\section{2) Mendelian susceptibility to mycobacterial infection in man}

Over the last 50 years familial cases of mycobacterial infection have been described where pedigree analysis suggested a single gene or Mendelian mutation was responsible for disease within families. Investigation of such families, which are nature's human equivalents of the knock-out mice, have provided important information on the pathways essential in humans for the control on mycobacterial infection. Work towards characterizing the molecular pathology in these families has led to the description of a new syn- drome, Mendelian Susceptibility to Mycobacterial Infection (MSMI, Mendelian Inheritance in Man \#209950), which has been reviewed recently [30, 31]. The best characterized of these families consisted of 4 Maltese children, two of whom were brothers and the offspring of parents who were second cousins, and were related to a third child as fourth cousins [32]. The pedigree structure suggested a single gene defect inherited recessively. Furthermore, it was likely that a single mutation arose in a common ancestor and the children were all homozygous for the same mutation. A single region of homozygosity was identified on chromosome $6 \mathrm{q}$, where the gene encoding the ligand binding chain (IFN $\gamma \mathrm{R} 1$ ) of the IFN- $\gamma$ receptor complex is located. Immunofluorescent studies showed the receptor was absent on leucocytes from the affected children and a mutation was identified, which introduced a premature stop codon resulting in a truncated protein that lacked the trans membrane and intracellular domains [33]. A different mutation was identified within this gene in a Tunisian child with disseminated BCG infection following vaccination [34].

Meanwhile, a retrospective study of disseminated $\mathrm{BCG}$ infection following vaccination revealed no underlying immunodeficiency in $50 \%$ of reported cases [35]. Four pairs of affected siblings were identified and parental consanguinity was observed in $30 \%$ of idiopathic cases [36] suggesting a number of these cases were due to Mendelian disorders. Sequence analysis of the IFNGRI gene in these families identified a number of other mutations. A spectrum of disease emerged which correlated with the molecular genetics. Nonsense mutations resulting in complete absence of protein expression were associated with severe and often fatal disease in early life $[33,34]$ whereas mutations resulting in reduced function of an expressed protein had a milder phenotype [37, 38]. However, mutation in this gene was excluded in some families, which led to the identification of mutation in 4 other genes with in the IFN- $\gamma / \mathrm{IL}$ 12 pathway: IFNGR2 which encodes the signal transducing chain of the IFN- $\gamma$ receptor complex [39], signal tranducer and activator of transcription 1 (STAT1), which is a signal transduction molecule involved in upregulation of IFN- $\gamma$ inducible genes [40], IL12B which encodes the p40 subunit of interleukin (IL)-12 [41] and ILI2RB1, which encodes the $\beta 1$ subunit of the IL-12 receptor $[42,43]$. As with IFNGRI, these original reports have led to the identification of many other affected families and new mutations [30]. These findings highlighted the important of the T helper type 1 lymphocyte responses in the control of intracellular pathogens such as mycobacteria. 


\section{3) Complex trait genetics: identification of common tuberculosis susceptibility genes in human populations}

There are two traditional study designs used to identify human susceptibility genes for complex traits including $\mathrm{TB}$, according to the groups studied. Firstly, population-based association studies search for genetic differences between individuals who have the disease (cases) compared to those who do not (controls). Secondly, family-based linkage studies search for genetic similarities in affected family members. Each approach has its attractions and drawbacks. In association studies, large numbers of cases and controls can be recruited, and this approach has the power to detect relatively small gene effects. However, it is important that cases and controls are properly matched to avoid spurious associations resulting from ethnic differences between groups. Linkage analysis has limited power to detect genes with a modest effect. Subsequently large numbers of families are required in order to obtain a significant result: for infectious disease studies it is usually difficult to collect large number of families with more than one generation represented and more than one affected individual. Furthermore, it is possible that an individual has inherited the susceptibility gene(s), but is classified as unaffected due to lack of exposure to the pathogen. This can be overcome by studying affected family members (usually siblings) only [44]. For these reasons, the majority of studies in genetics of infectious diseases have been association studies.

There are two methodological approaches to identify the specific genes involved: candidate gene studies and genome wide scanning. A candidate gene approach targets a specific gene, which is implicated in disease pathogenesis, for example as a result of murine or Mendelian human studies described above. Candidate genes may be studied by linkage in families or by association in populations. Genome wide scanning is currently limited to family-based linkage studies. Polymorphic markers across the whole genome are typed in family members and when co-inheritance of markers with the trait occurs, the marker is said to be linked to the disease. This approach has the capacity to identify new genes that are important in disease pathogenesis but so far undiscovered. A comprehensive search for regions associated with tuberculosis using an association study design requires a much denser marker saturation across the genome. This increases the logistical effort and cost of such studies and further technical advances are required to make this approach affordable and feasible.

Studies of TB illustrate the problems that researchers of complex diseases encounter, the most important of which is the poor reproduciability of results. In the majority of the published datasets a small sample (usually in the range of a few hundred cases and controls) has been studied. Such studies have little power to detect modest association (e.g. relative risk below 2) [45] and the low statistical power of some small studies may ex- plain their failure to replicate true associations observed previously. Studies attempting to investigate interactions between several genetic factors or gene-environment interactions require even bigger samples to avoid these problems. False positive associations may occur as a result of population admixture. Additionally, it is well established that association between a genetic marker and a disease may appear as a result of its close proximity to a causal variant (known as linkage disequilibrium, LD) in some populations, but not in others. Clinical heterogeneity of TB patients in various studies is a further confounding factor which may explain some differences in the observed association.

\section{TB susceptibility genes identified to date}

\section{1) Role of the human MHC genes in susceptibility to $T B$}

The most consistent TB susceptibility association has been with the genes of the major histocompatibility complex (MHC) also known as human leukocyte antigens (HLA) region. The MHC region is located on the short arm of chromosome 6 and harbours over 120 genes, many of which are involved in immune responses. The MHC is conventionally divided into three regions: the centromeric class II region (encoding the MHC class II molecules DQ, DR and DP), the telomeric class I region (encoding the MHC class I A, B and C molecules and non-classical molecules e.g. E, F and G). The Class III region lies between the class I and II regions. The classical MHC class I and class II molecules are extremely polymorphic. The high degree of variation is maintained by balancing selection and is crucial for the binding of various antigenic peptides, the main function of these proteins. Short peptides are then presented on the cell surface where they are recognised in the context of the classical class I or class II MHC molecules by $\mathrm{CD} 8+$ or $\mathrm{CD} 4+\mathrm{T}$ cells, respectively. Since MHC molecules are the major component of the immune system it is not surprising that polymorphisms of these molecules are associated with various immune-mediated diseases such as infection and autoimmune disorders. However, strong LD exists between the genes across the MHC region which complicates precise identification of the gene responsible for a given disorder.

A number of studies on the role of the MHC in susceptibility to TB have been published in many different populations (table 2). Despite the difficulties outlined in the previous section, several conclusions can be made. Evidence for association with TB is more consistent for the class II than for class I genes. In particular, the DR2 allele of the $D R B 1$ gene is often associated with the increased risk of TB and never with protection. These observations suggest that MHC harbours at least one gene that influences risk of TB and indicate its probable location within the MHC class II region. However, genetic association of the DR2 allele itself does not necessarily prove its causal role, but may merely reflect the LD that exists between this 
Table 2. - Association studies of the MHC class I and II genes with TB

\begin{tabular}{|c|c|c|c|c|c|}
\hline \multirow[t]{2}{*}{ Population } & \multicolumn{2}{|l|}{ MHC Class I } & \multicolumn{2}{|l|}{ MHC Class II } & \multirow[t]{2}{*}{ Reference } \\
\hline & Risk & Protective & Risk & Protective & \\
\hline Newfoundland & B8 & & NT & NT & [50] \\
\hline Greek & A1, B27 & & NT & NT & [51] \\
\hline Russian & B17, B5 & & DR2 & DR3 & [52] \\
\hline Polish & NT & NT & DR16 (DR2) & DR13 (DR6) & [53] \\
\hline Polish & B15, Cw5 & & NT & NT & [54] \\
\hline Armenian & A1, B12, B35, & & DR2 & DR3 & [52] \\
\hline Moldavian & B5 & A10, Cw9 & NT & NT & [52] \\
\hline Kazakh & A2, B14, B35 & $\mathrm{A} 3, \mathrm{Cw} 1$ & DR2 & DR3 & [52] \\
\hline Turkmen & & & DR2 & DR3 & [52] \\
\hline Uzbekh & B12 & & DR2 & DR3 & [52] \\
\hline Tuvinian & B15 & & DR2, DRw53 & & [55] \\
\hline Mexican-American & B15 & & NT & NT & [56] \\
\hline Mexican-American & & & & DR3 & [57] \\
\hline Mexican & & & $\begin{array}{l}\text { DRB1*1501 } \\
(\text { DR2), } \\
\text { DQA } 1 * 0101, \\
\text { DQB } 1 * 0501\end{array}$ & $\begin{array}{l}\text { DR4, } \\
\text { DR8, } \\
\text { DQB1*0402 }\end{array}$ & [58] \\
\hline African-American & $\mathrm{B} 15$ & & NT & NT & [59] \\
\hline African-American & & B5 & DR5 & DR6 & {$[60]$} \\
\hline Egyptian & A2, B5 & & & & [61] \\
\hline Japanese & & & NT & NT & [62] \\
\hline Chinese & B27, B35 & A19, B15 & NT & NT & [63] \\
\hline Chinese & & A11 & DR8 & & [64] \\
\hline Cambodian & B38 & & DQB $1 * 0503$ & & [65] \\
\hline Thai & NT & NT & DQB $1 * 0501$ & $\begin{array}{l}\text { DQB } 1 * 0301, \\
\text { DQA } 1 * 0601\end{array}$ & [66] \\
\hline Indonesian & & & DR2, DQ1 & DQ3 & [67] \\
\hline Indian & & & DR2 & & [68] \\
\hline Indian & & & & DR6 & [69] \\
\hline Indian & B18 & & NT & NT & [70] \\
\hline Indian & & & NT & NT & [71] \\
\hline Indian & A10, B8, B14 & $\begin{array}{l}\text { A24, A19, } \\
\text { B52, B57, B61 }\end{array}$ & DR2 & & [72] \\
\hline Indian & NT & NT & DQB $1 * 0503$ & & [73] \\
\hline Indian & NT & NT & DR2 & & [74] \\
\hline Indian & & & DR2 & & [75] \\
\hline Indian & NT & NT & $\begin{array}{l}\text { DRB1*1501 } \\
(\mathrm{DR} 2), \\
\text { DRB1*08 (DR8), } \\
\text { DQB } 1 * 0601, \\
\text { DPB } 1 * 02\end{array}$ & $\begin{array}{l}\text { DRB } 1 * 10, \\
\text { DRB1*11, } \\
\text { DQB1*0501, } \\
\text { DPB } 1 * 08\end{array}$ & [76] \\
\hline
\end{tabular}

NT - not tested; blank cell indicates that no association was found. 
allele and alleles of other MHC genes. It is also possible that more than one $\mathrm{MHC}$ gene influences the risk of TB, as was discovered in other MHCassociated diseases, e.g. autoimmune type 1 diabetes $[46,47]$. Functional data show that both CD4+ and CD8+ cells are crucial in the immune response to MTB $[48,49]$ suggesting variation in both MHC class II and class I genes, respectively, may have an aetiological role in TB. High-resolution genotyping of multiple markers in large and statistically powerful samples from various populations is required to dissect the independent effects of different MHC genes on susceptibility to TB.

\section{2) SLC11A1 (formerly NRAMP1)}

Of all the genes associated with TB to date SLC11A1 (solute carrier family 11 member 1 , formerly known as natural resistance associated macrophage protein 1 NRAMPl) is the best characterized. Initially identified as a murine mycobacteria susceptibility gene [77], Slc1lal was positionally cloned and a point mutation, resulting in the substitution of glycine to aspartic acid at position 169, was identified in the susceptible allele [78]. The human homologue, SLC11A1, was cloned and variation in this gene has been studied in relation to TB susceptibility in a number of genetically different human populations.

The first study to demonstrate an association between TB susceptibility and SLC11A1 was a case control study conducted in The Gambia, in which 4 different SLC11AI polymorphisms (5'complex repeat, INT4, D543N and 3'UTR, as described in [79]) were found to be associated with TB with odds ratios (OR) ranging from 1.1 to 1.9 [80]. Heterozygosity for both the INT4 and 3'UTR alleles led to a four-fold increased risk of TB. This finding was followed up by the same group who reported a significant association $(P<0.04)$ between the INT4 polymorphism in a family-based association study in Guinea-Conakry [81]. The 5 'complex repeat is functional and influences SLC11A1 expression in a luciferase reporter system [82]. Allele 3 drives high expression relative to the other alleles, which is enhanced by lipopolysaccharide (LPS) and this allele has been associated with resistance to TB [80]. Conversely, allele 2 is associated with lower promoter activity and susceptibility to TB. The association between allele 2 of the SLC11A1 5' complex repeat and TB has been confirmed in a second Gambian population sample [83]. This study also reported data to suggest that SLC11AI mediates its effect via the downregulatory cytokine IL-10.

Significant linkage $\left(P<2 \times 10^{-5}\right)$ between SLC11A1 and TB was identified in a large Aboriginal Canadian family [84], while no linkage was observed in 116 Moroccan families [85]. Associations between SLC11A1 and TB have been tested in other populations. The 5'complex repeat is associated with TB in Japan (OR 2.1) [86] and American Caucasians [87]. The 3' UTR variant that is associated with TB in The Gambia appears to be associated with TB in Koreans (OR 1.9) [88] but the same allele confers resistance in Cambodians (OR 0.59) [89]. The D543N SLC11A1 polymorphism is also associated with resistance to TB in this population. No association was found in a Taiwanese population sample [90]. Such discrepant findings are common in the genetics of complex diseases (see above) and suggest that additional replication in more powerful samples representing different populations is required. Finally, there is some preliminary evidence that SLC11A1 may regulate the type of disease that develops upon infection with MTB. Variation in this gene has been associated with tuberculous pleurisy [91], cavitating disease [92] and microscopy-positive disease [93]. Studies specifically designed to confirm or reject these associations are needed before any conclusion can be made.

\section{3) Vitamin D receptor}

Tuberculosis is more common in groups at risk of dietary deficiency of vitamin D [94], and indirect vitamin $\mathrm{D}$ therapy (e.g. exposure to sunlight, cod liver oil) was used to treat TB before the introduction of chemotherapy. Serum 1,25-dihydroxyvitamin $\mathrm{D}_{3}$, the active metabolite of vitamin $\mathrm{D}$, is low in patients with untreated TB $[95,96]$ and levels correlated with disease severity in a study in Indonesia [97]. In addition to its function in bone metabolism, vitamin D has important immunomodulatory effects of relevance to mycobacterial immunity. Acting via the vitamin D receptor (VDR), which is widely expressed on monocytes and activated lymphocytes, 1,25 dihydroxyvitamin $\mathrm{D}_{3}$ activates monocytes to suppress the growth of MTB [98, 99]. These epidemiological and immunological observations have led to the investigation of the VDR as a candidate gene for TB susceptibility. A silent $\mathrm{T}>\mathrm{C}$ single nucleotide polymorphism at codon 352 in the VDR gene was investigated in the Gambian population sample described above. Homozygotes for the $\mathrm{C}$ allele were under-represented in the TB cases, suggesting a protective influence for this genotype (OR 0.53) [100]. However, no association was found between this genotype and TB in a Gujarati population sample in west London [96], Southern Indians [101] or in Cambodians [89]. However, when the codon 352 SNP genotype was considered together with the serum level of 1,25 dihydroxyvitamin $\mathrm{D}_{3}$ in the Gujarati study, the CC homozygous genotype appeared to offer protection against TB in vitamin D deficient patients [96]. This suggests complex interactions between both genes and environmental factors in the development of disease, and the need for studies specifically designed to investigate such interactions.

\section{4) IFN- $\gamma / I L-12$ pathway}

The single gene defects that lead to increased susceptibility to mycobacteria disease emphasize the importance of macrophage activation through the IFN- $\gamma /$ IL-12 pathway in controlling mycobac- 
terial infections. Phenotype-genotype correlations within this group of rare disorders suggest a spectrum exists in which complete deficiency of either chain of the IFN- $\gamma$ receptor complex results in severe fatal disease yet partial deficiency of IFN- $\gamma \mathrm{R} 1$ or complete deficiency of either IL-12 p40 or IL$12 \mathrm{R} \beta 1$ leads to milder disease that responds to treatment with either anti-mycobacterial chemotherapy or IFN- $\gamma[102,103]$. There are also family members who have inherited disease-associated genotypes but remain well [104]. It is therefore conceivable that common variants in any of the genes in this pathway underlie susceptibility to more virulent species such as MTB in the general population. Support for this hypothesis comes from three separate studies (in Cape Town, Spain and Sicily), which report associations between a SNP in the first intron of the IFN- $\gamma$ gene $(+874 \mathrm{~T}>\mathrm{A})$ and TB [105-107]. This SNP lies within a binding site for the transcription factor NFkap$\mathrm{paB}$ and influences binding of this protein at this site. The allele that is associated with susceptibility to TB is associated with reduced IFN- $\gamma$ production in vitro [105] which adds biological plausibility to the genetic association study results. Of the Mendelian genes themselves, differences in allele distribution frequencies for a microsatellite marker within IFNGRI has been reported in a small Croatian sample, but not confirmed in a larger sample from the Gambia [108, 109]. SNPs within the IFNGRI gene also show no association with TB in Gambians [110]. There has been one study published on ILI2RBI and TB - this was conducted in a Japanese sample and showed an association between three coding region SNPs (which were in complete LD) and TB [111]. There are no reported associations between TB and the other MSMI genes IFNGR2 and IL12B and STAT1. Thus there is some evidence that the genes involved in MSMI also play a role in TB in outbred populations, but further studies are required.

\section{5) Miscellaneous other genes}

In addition to the genes described in more detail above, researchers have reported associations between variation in IL-1 $\beta$ [112], IL-10 [89], mannose binding lectin [113, 114], IL-8 [115], and the purinergic receptor $\mathrm{P} 2 \mathrm{X} 7$ [116] and TB. These are mostly single reports and for some of the genes there are conflicting data suggesting no association [89, 117, 118], while unconfirmed positive findings may have arisen by chance and publication bias [119].

\section{6) Genome scanning in $\mathrm{TB}$}

A genome wide scan to identify regions of the genome linked to TB has been conducted in a sample of 92 affected sibling pairs (ASP) followed by a second sample of 81 ASP from Gambia and South Africa [120]. LOD scores of 2.0 and 1.7 were obtained for regions on chromosomes 15 and $\mathrm{X}$ respectively. Fine mapping studies of the region on chromosome 15 have been undertaken and UBE3A, ubiquitin protein ligase E3A, identified as a putative TB susceptibility gene in this region [121]. It is noteworthy that none of the candidate genes identified by association came up in this linkage scan. This is a reminder that linkage studies using small numbers of families have very little power to detect multiple minor effects that

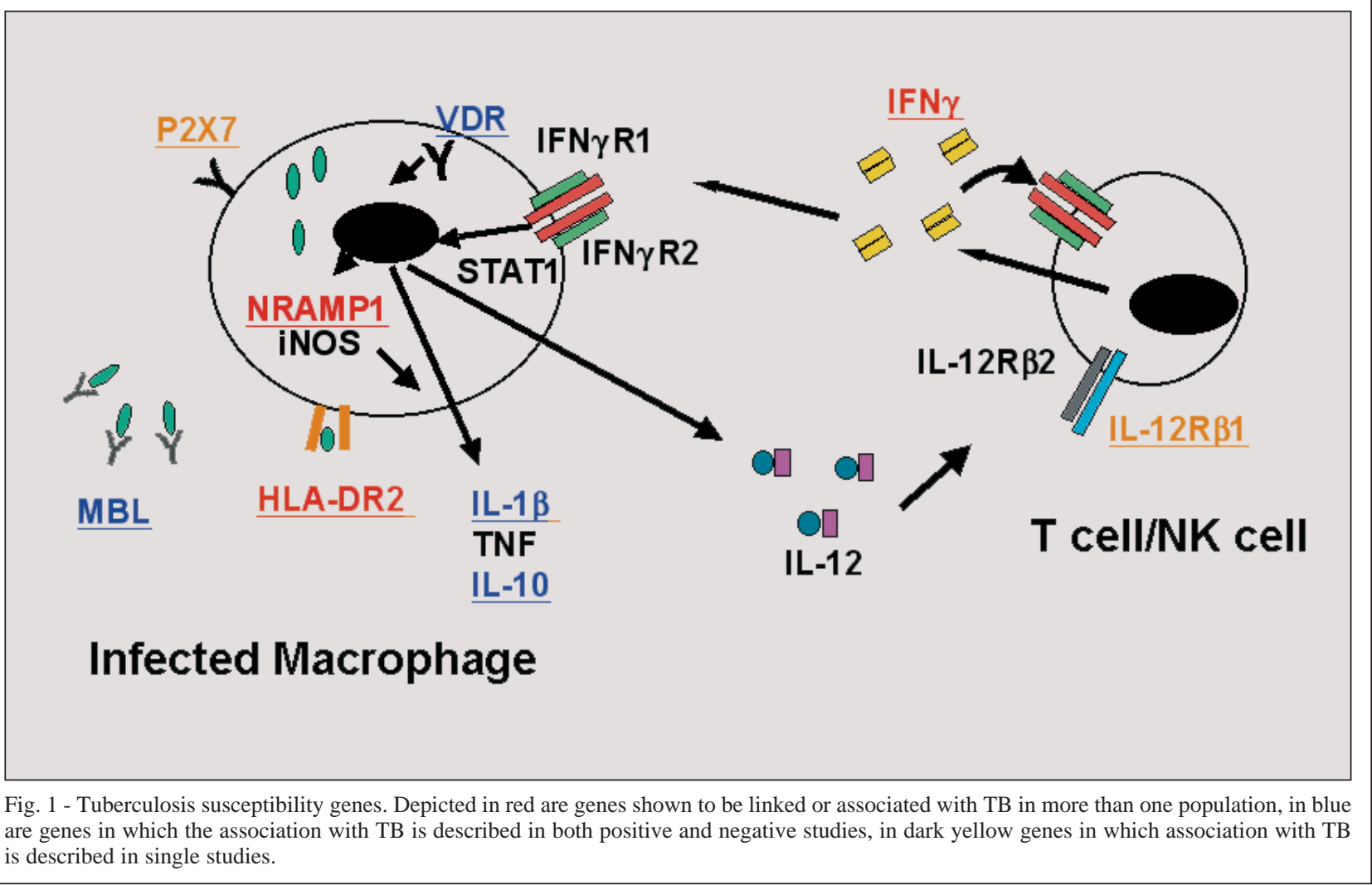


probably contribute to the overall phenotype [122]. Much bigger collections of affected sib pairs, perhaps in a range of 1,000 or more [123] are required to provide a reliable guidance for geneticists. Collection of such samples is achievable and is already underway for a consortium of researchers working in the area of type 1 diabetes, another complex disease (http://www.t1dgc.org/).

\section{Conclusions}

TB is a complex trait that occurs in genetically susceptible individuals who are infected with MTB and exposed to environmental factors that influence the host immune response. It is hoped that the characterization of the genes involved will identify pathways that are required for host defence against $\mathrm{TB}$ and lead to the development of better vaccines and therapies for what is a major global public health problem. A number of approaches have led to significant progress in the field over the last few years. Much has been learnt from rare familial defects in mycobacterial immunity. At the population level, association studies indicate that sequence variation in the IFN $\gamma$ and SLC11A1 genes probably contributes to common TB susceptibility. Markers in the MHC region have consistently been associated with TB across many populations, which suggest existence of a TB gene or genes in this region. However, at present, genetic evidence is insufficient to identify this gene(s). The effect of each TB-associated gene identified to date is modest, their combined effect is not sufficient to explain fully the genetic contribution to the aetiology of tuberculosis, suggesting need for future research. However, studies are often conflicting or inconclusive as a result of ineffective design. Perhaps it is time for researchers to joint their efforts and form a consortium to develop international cohorts with statistical power to convincingly identify TB genes and approach studies of gene-gene and gene-environment interactions.

\section{References}

1. Dye C, Scheele S, Dolin P, V. P, Raviglione MC. Consensus statement. Global burden of tuberculosis: estimated incidence, prevalence, and mortality by country. WHO global surveillance and monitoring project. JAMA 1999; 282: 677-686.

2. Fine PEM. Variation in protection by BCG: implications of and for heterologous immunity. Lancet 1993; 346: 1339-1345.

3. Dye C, Espinal MA, Watt CJ, Mbiaga C, Williams BG. Worldwide incidence of multidrug-resistant tuberculosis. J Infect Dis 2002; 185: 1197-1202.

4. Sorensen TIA, Nielson GG, Andersen PK, Teasdale TW. Genetic and environmental influences on premature death in adult adoptees. New Engl J Med 1988; 318: 727-732.

5. Fine PEM. Immunogenetics of susceptibility to leprosy, tuberculosis and leishmania. An epidemiological perspective. Int J Lepr 1981; 49: 437-454.

6. Stead WW, Senner JW, Reddick WT, Lofgren JP. Racial differences in susceptibility to infection by $M y$ - cobacterium tuberculosis. N Engl J Med 1990; 322: 422-427.

7. Stead WW. Genetics and resistance to tuberculosis. Ann Intern Med 1992; 116: 937-994.

8. Motulsky AG. Metabolic polymorphisms and the role of infectious diseases in human evolution. Hum Biol 1960 (32): 28-62.

9. Sousa AO, Salem JI, Lee FK, et al. An epidemic of tuberculosis with a high rate of tuberculin anergy among a population previously unexposed to tuberculosis, the Yanomami Indians of the Brazil Amazon. Proc Natl Acad Sci USA 1997; 94: 13227-13232.

10. Kallman FJ, Reisner D. Twin studies on genetic variations in resistance to tuberculosis. J Hered 1943; 34: 293-301.

11. Comstock G. Tuberculosis in twins: a re-analysis of the prophit survey. Am Rev Respir Dis 1978; 117: 621-624.

12. Orme IM. The mouse as a useful model for tuberculosis. Tuberculosis 2003; 83: 112-115.

13. Pfeffer K, Mak TW. Lymphocyte ontogeny and activation in gene targeted mutant mice. Annu Rev Immunol 1994; 12: 367-411.

14. Erb KJ, Kirman J, Delahunt B, Chen W, LeGros G. IL4, IL-5 and IL-10 are not required for the control of M. bovis-BCG infection in mice. Immunol Cell Biol 1998; 76: 41-46.

15. Laochumroonvorapong $\mathrm{P}$, Wang J, Liu CC, et al. Perforin, a cytotoxic molecule which mediates cell necrosis, is not required for the early control of mycobacterial infection in mice. Infect Immun 1997; 65: 127-132.

16. Kaufmann SH. Immune response to tuberculosis: experimental animal models. Tuberculosis 2003; 83: 107111.

17. Vidal S, Tremblay ML, Govoni G, et al. The Ity/ $\mathrm{Lsh} / \mathrm{Bcg}$ locus: natural resistance to infection with intracellular parasites is abrogated by disruption of the Nramp1 gene. J Exp Med 1995; 182: 655-666.

18. Flynn JL, Goldstein MM, Chan J, Triebold KJ, Pfeffer $\mathrm{K}$, Lowenstein CJ, et al. Tumor necrosis factor- $\alpha$ is required in the protective immune response against $M y$ cobacteruim tuberculosis in mice. Immunity 1995; 2: 561-572.

19. Cooper AM, Dalton DK, Stewart TA, Griffin JP, Russell DG, Orme IM. Disseminated tuberculosis in IFN- $\gamma$ gene disrupted mice. J Exp Med 1993; 178: 2243-2247.

20. Flynn JL, Chan J, Triebold KJ, Dalton DK, Stewart TA, Bloom BR. An essential role for interferon $\gamma$ in resistance to Mycobacterium tuberculosis infection. $J$ Exp Med 1993; 178: 2249-2254.

21. Kamijo R, Le J, Shapiro D, Havell EA, Huang S, Aguet $\mathrm{M}$, et al. Mice that lack the interferon-gamma receptor have profoundly altered responses to infection with Bacillus Calmette-Guerin and subsequent challenge with lipopolysaccharide. J Exp Med 1993; 178: 143540.

22. Flynn JL, Goldstein MM, Treibold KJ, Koller B, Bloom BR. Major histocompatibility complex class I-restricted $\mathrm{T}$ cells are required for resistance to Mycobacterium tuberculosis infection. Proc Natl Acad Sci USA 1992; 89: 12013-12017.

23. Ladel $\mathrm{CH}$, Dauglat $\mathrm{S}$, Kaufmann SHE. Immune responses to Mycobacterium bovis bacille Calmette Guerin infection in major histocompatibility complex class I- and II deficient mice: contribution of CD4 and CD8 cels to acquired resistance. Eur J Immunol 1995; 25: 377-384.

24. Ladel CH, Hess J, Daugelet S, Mombaerts P, Tonegawa S, Kaufmann SHE. Contribution of $\alpha / \beta$ and $\gamma / \delta$ T lymphocytes to immunity against Mycobacterium bovis bacillus Calmette Guerin: studies with $\mathrm{T}$ cell receptor deficient mutant mice. Eur J Immunol 1995; 25: 838846. 
25. Kamijo R, Harada H, Matsuyama T, et al. Requirement for transcription factor IRF-1 in NO synthase induction in macrophages. Science 1994; 263: 1612-1615.

26. Ladel CH, Blum C, Dreher A, Reifenberg K, Kopf M, Kaufmann SH. Lethal tuberculosis in interleukin-6-deficient mutant mice. Infect Immun 1997; 65: 4843-4849.

27. Cooper AM, Magram J, Ferrante J, Orme IM. Interleukin-12 (IL-12) is crucial to the development of protective immunity in mice intravenously infected with Mycobacterium tuberculosis. J Exp Med 1997; 186: 39-45.

28. Scanga CA, Mohan VP, Tanaka K, Alland D, Flynn JL, Chan J. The inducible nitric oxide synthase locus confers protection against aerogenic challenge of both clinical and laboratory strains of Mycobcaterium tuberculosis. Infect Immun 2001; 69: 7711-7717.

29. Abel B, Thieblemont N, Quesniaux VJF, et al. Toll-like receptor 4 expression is required to control chronic $M y$ cobacterium tuberculosis infection in mice. J Immunol 2002; 169: 3155-3162.

30. Newport MJ, Holland SM, Levin M, Casanova J-L. Inherited disorders of the interleukin-12-interferon gamma axis. In: Ochs HD, Smith E, Puck JM, editors. Primary Immunodeficiency Diseases. A Molecular and Genetic Approach. Oxford: Oxford University Press; 2004.

31. Newport MJ. The genetics of nontuberculous mycobacterial infection. Exp Rev Mol Med 2003; http: //www.expertreviews.org/03005908h.htm (28th February 2003).

32. Levin M, Newport MJ, D'Souza S, et al. Familial disseminated atypical mycobacterial infection in early childhood: a human mycobacterial susceptibility gene? Lancet 1995; 345: 79-83.

33. Newport MJ, Huxley CM, Huston S, et al. A mutation in the interferon-gamma receptor gene and susceptibility to mycobacterial infections in man. $N$ Engl $J$ Med 1996; 335: 1941-1949.

34. Jouanguy E, Altare F, Lamhamedi S, et al. Interferongamma-receptor deficiency in an infant with fatal bacille Calmette-Guerin infection. N Engl J Med 1996; 335: 1956-1959.

35. Casanova JL, Jouanguy E, Lamhamedi S, Blanche S, Fischer A. Immunological conditions of children with BCG disseminated infection. Lancet 1995; 346: 581.

36. Casanova J-L, Blanche S, Emile J-F, et al. Idiopathic disseminated bacille Calmette-Guerin infection: a French national retrospective study. Pediatrics 1996; 98: 774-778.

37. Jouanguy E, Lamamedi-Cherradi S, Altare F, et al. Partial interferon- $\gamma$ receptor 1 deficiency in a child with tuberculoid bacillus Calmette-Guerlin infection and a sibling with clinical tuberculosis. J Clin Invest 1997; 100: 2658-2664.

38. Jouanguy E, Lamhamedi-Cherradi S, Lammas D, et al. A human IFNGRI small deletion hotspot associated with dominant susceptibility to mycobacterial infection. Nat Genet 1999; 21: 370-378.

39. Dorman SE, Holland SM. Mutation in the signal transducing chain of the interferon-gamma receptor and susceptibility to mycobacterial infection. J Clin Invest 1998; 101: 2364-2369.

40. Dupuis S, Dargemont C, Fieschi C, et al. Impairment of mycobacterial but not viral immunity by a germline human STAT1 mutation. Science 2001; 293: 300-303.

41. Altare F, Durandy A, Lammas D, et al. Impairment of mycobacterial immunity in human interleukin-12 receptor deficiency. Science 1998; 280: 1432-1435.

42. de Jong R, Altare F, Haagen I-A, et al. Severe mycobacterial and Salmonella infections in interleukin-12 receptor deficient patients. Science 1998; 280: 14351438 .
43. Altare F, Lammas D, Revy P, et al. Inherited interleukin 12 deficiency in a child with Bacille CalmetteGuerin and Salmonella enteritidis disseminated infection. J Clin Invest 1998; 102: 2035-2040.

44. Hauser ER, Boehnke M, Guo S-W, Risch N. Affectedsib-pair interval mapping and exclusion for complex genetic traits. Genet Epidemiol 1996; 13: 117-137.

45. Dahlman I, Eaves IA, Kosoy R, et al. Parameters for reliable results in genetic association studies in common disease. Nat Genet 2002; 30: 149-150.

46. Nejentsev S, Gombo Z, Laine AP, et al. Non-class II HLA gene associated with type 1 diabetes maps to the 240-kb region near HLA-B. Diabetes 2000; 49: 2217 2221.

47. Nejentsev S, Reijonen H, Adojaan B, et al. The effect of HLA-B allele on the IDDM risk defined by DRB1*04 subtypes and DQ1*0302. Diabetes 1997; 46: 1888-1892.

48. Flynn JL, Chan J. Immunology of tuberculosis. Annu Rev Immunol 2001; 19: 93-129.

49. Lazarevic V, Flynn J. CD8+ T cells in tuberculosis. Am J Respir Crit Care Med 2002; 166: 1116-1121.

50. Selby R, Bernard MJ, Buehler KS, Crumley J, Larsen B, Marshall WH. Tuberculosis associated with HLAB8, BfS in a Newfoundland community. Tissue Antigens 1978; 11: 403-408.

51. Zervas J, Constantopoulos C, Toubis M, Anagnostopoulos D, Cotsovoulou V. HLA-A and B antigens and pulmonary tuberculosis in Greeks. Br J Dis Chest 1987; 81: $147-149$.

52. Khomenko AG, Litvinov VI, Chukanova VP, Pospelov LE. Tuberculosis in patients with various HLA phenotypes. Tubercle 1990; 71: 187-192.

53. Dubaniewicz A, Lewko B, Moszkowska G, Zamorska B, Stepinski J. Molecular subtypes of the HLA-DR antigens in pulmonary tuberculosis. Int $J$ Infect Dis 2000; 4: 129-

54. Dubaniewicz A, Szczerkowska Z, Hoppe A. Molecular subtypes of the HLA-DR antigens in pulmonary sarcoidosis and tuberculosis in the same ethnic group. Mayo Clin Proc 2003; 78: 429-442.

55. Pospelov LE, Matrakshin AG, Chernousova LN, et al. Association of various genetic markers with tuberculosis and other lung diseases in Tuvinian children. Tubercle and Lung Disease 1996; 77: 77-80.

56. Cox RA, Arnold DR, Cook D, Lundberg DI. HLA phenotypes in Mexican Americans with tuberculosis. Am Rev Respir Dis 1982; 126: 653-655.

57. Cox RA, Downs M, Neimes RE, Ognibene AJ, Yamashita TO, Ellner JJ. Immunogenetic analysis of human tuberculosis. J Infect Dis 1988; 158: 1302-1308.

58. Teran-Escandon D, Teran-Ortiz L, Camarena-Olvera A, et al. Human leukocyte antigen-associated susceptibility to pulmonary tuberculosis: molecular analysis of class II alleles by DNA amplification and oligonucleotide hybridization in Mexican patients. Chest 1999; 115: 428433.

59. Al-Arif LI, Goldstein RA, Affronti LF, Janicki W HLA-Bw15 and tuberculosis in a North American black population. Am Rev Respir Dis 1979; 120: 1275-1278.

60. Hwang $\mathrm{CH}$, Khan S, Ende N, Mangura BT, Reichman LB, Chou J. The HLA-A, -B, and -DR phenotypes and tuberculosis. Am. J. Respir. Dis. 1985; 132: 382-385.

61. Hafez M, El-Salab SH, El-Shennawy F, Bassiony MR. HLA-antigens and tuberculosis in the Egyptian population. Tubercle 1985; 66: 35-40.

62. Takata H, Sada H, Ozawa S, Sekiguchi S. HLA and mycobacterial infection: increased frequency of B8 in Japanese leprosy. Tissue Antigens 1978; 11: 61-64.

63. Jiang ZF, An JB, Sun YP, Mittal KK, Lee TD. Association of HLA-Bw35 with tuberculosis in the Chinese. Tissue Antigens 1983; 22: 86-88. 
64. Hawkins BR, Higgins DA, Chan SL, Lowrie DB, Mitchison DA, Girling DJ. HLA typing in the Hong Kong Chest Service/British Medical Research Council study of factors associated with the breakdown to active tuberculosis of inactive pulmonary lesions. Am Rev Respir Dis 1988; 138: 1616-1621.

65. Goldfeld AE, Delgado JC, Thim S, et al. Association of an HLA-DQ allele with clinical tuberculosis. JAMA 1998; 279: 226-228.

66. Vejbaesya S, Chielakul N, Luangtrakool K, Srinak D, Stephens HA. Associations of HLA class II alleles with pulmonary tuberculosis in Thais. J Immunogenet 2002; 29: 431-434

67. Bothamley GH, Beck JS, Geziena M, et al. Association of tuberculosis and M. tuberculosis-specific antibody levels with HLA. J Infect Dis 1989; 59: 549-555.

68. Singh SPN, Mehra NK, Dingley HB, Pande JN, Vaidya MC. Human leukocyte antigen (HLA)-linked control of susceptibility to pulmonary tuberculosis and association with HLA-DR types. J Infect Dis 1983; 148: 676681.

69. Singh SPN, Mehra NK, Dingley HB, Pande JN, Vaidya MC. HLA-A, -B, -C and -DR antigen profile in pulmonary tuberculosis in North India. Tissue Antigens 1983; 21: 380-384.

70. Papiha SS, Wentzel J, Behjati F, Agarwal SS. Human leukocyte antigens and circulating immunoglobulin levels in Indian patients with pulmonary tuberculosis. Tubercle 1985; 66: 25-33.

71. Papiha SS, Singh BN, Lanchbury JS, et al. Association of HLA and other genetic markers in South Indian patients with pulmonary tuberculosis. Tubercle 1987; 68: 159-167.

72. Brahmajothi V, Pitchappan RM, Kakkanaiah VN, et al. Association of pulmonary tuberculosis and HLA in South India. Tubercle 1991; 72: 123-132.

73. Sanjeevi CB, Narayanan PR, Prabakar R, et al. No association or linkage with HLA-DR or -DQ genes in south Indians with pulmonary tuberculosis. Tuber Lung Dis 1992; 73: 280-284.

74. Selvaraj P, Reetha AM, Uma $\mathrm{H}$, et al. Influence of HLA-DR and -DO phenotypes on tuberculin reactive status in pulmonary tuberculosis patients. Tuber Lung Dis 1996; 77: 369-373.

75. Rajalingam R, Mehra NK, Jain RC, Myneedu VP, Pande JN. Polymerase chain reaction-based squence specific oligonucleotide hybridization analysis of HLA class II antigens in pulmonary tuberculosis: relevance to chemotherapy and disease severity. J Infect Dis 1996; 173: 669-676.

76. Ravikumar M, Dheenadhayalan V, Rajaram K, et al. Associations of HLA-DRB1, DQB1 and DPB1 alleles with pulmonary tuberculosis in south India. Tuber Lung Dis 1999; 79: 309-317.

77. Gros P, Skamene E, Forget A. Genetic regulation of natural resistance to Mycobacteruim bovis BCG. J Immunol 1981; 127: 2417-2421

78. Vidal SM, Malo D, Vogan K, Skamene E, Gros P. Natural resistance to infection with intracellular parasites: Isolation of a candidate for Bcg. Cell 1993; 73: 469485.

79. Liu J, Fujiwara TM, Buu NT, et al. Identification of polymorphisms and sequence variants in the human homologue of the mouse natural resistance-associated macrophage protein gene. Am J Hum Genet 1995; 56 : 845-853.

80. Bellamy R, Ruwende C, Corrah T, McAdam KPW, Whittle HC, Hill AVS. Variations in the NRAMP1 gene and susceptibility to tuberculosis in West Africans. $N$ Engl J Med 1998; 338: 640-644.

81. Cervino AC, Lakiss S, Sow O, Hill AV. Allelic association between the NRAMP1 gene and susceptibility to tuberculosis in Guinea-Conakry. Ann Hum Genet 2000; 64: $507-512$

82. Searle S, Blackwell JM. Evidence for a functional repeat polymorphism in the promoter region of human NRAMP1 that correlates with infectious versus autoimmune disease susceptibility. J Med Genet 1999; 36: 295-299.

83. Awomoyi AA, Marchant A, Howson JMM, McAdam KPWJ, Blackwell JM, Newport MJ. Interleukin-10, polymorphism in SLC11A1 (formerly NRAMP1) and susceptibility to tuberculosis. J Infect Dis 2002; 186: 1808-1814.

84. Greenwood CMT, Fujiwara TM, Boothroyd LJ, et al. Linkage of tuberculosis to chromosome 2q35 loci, including NRAMP1, in a large Aboriginal Canadian family. Am J Hum Genet 2000; 67: 405-416.

85. El Baghdadi J, Remus N, Benslimane A, et al. Variants of the human NRAMP1 gene and susceptibility to tuberculosis in Morocco. Int J Tuberc Lung Dis 2003; 7: 599-602.

86. Gao PS, Fujishima S, Mao XQ, et al. Genetic variants of NRAMP1 and active tuberculosis in Japanese populations. International Tuberculosis Genetics Team. Clin Genet 2000; 58: 74-76.

87. Ma X, Dou S, Wright JA, et al. 5' dinucleotide repeat polymorphism of NRAMP1 and susceptibility to tuberculosis among Caucasian patients in Houston, Texas. Int J Tuberc Lung Dis 2002; 6: 818-823.

88. Ryu S, Park YK, Bai GH, Kim SJ, Park SN, Kang S. 3' UTR polymorphisms in the NRAMP1 gene are associated with susceptibility to tuberculosis in Koreans. Int $J$ Tuberc Lung Dis 2000; 4: 577-580.

89. Delgado JC, Baena A, Thim S, Goldfeld AE. Ethnicspecific genetic associations with pulmonary tuberculosis. J Infect Dis 2002; 186: 1463-1468.

90. Liaw YS, Tsai-Wu JJ, Wu CH, et al. Variations in the NRAMP1 gene and susceptibility of tuberculosis in Taiwanese. Int J Tuberc Lung Dis 2002; 6: 454-460.

91. Kim JH, Lee SY, Sin C, et al. NRAMP1 genetic polymorphisms as a risk factor of tuberculous pleurisy. Int J Tuberc Lung Dis 2003; 7: 370-375.

92. Abe T, Iinuma Y, Ando M, et al. NRAMP1 polymorphisms, susceptibility and clinical features of tuberculosis. J Infect 2003; 46: 215-220.

93. Soborg C, Andersen AB, Madsen HO, Kok-Jensen A, Skinhoj P, Garred P. Natural resistance-associated macrophage protein 1 polymorphisms are associated with microscopy-positive tuberculosis. J Infect Dis 2002; 186: 517-521.

94. Strachan DP, Powell KJ, Thaker A, Millard FJC, Maxwell JD. Vegetarian diet as a risk factor for tuebrculosis in immigrnat south London Asians. Thorax 1995; 50: 175-180.

95. Davies PDO, Brown RC, Woodhead JS. Serum concentrations of vitamin D metabolites in untreated tuberculosis. Thorax 1985; 40: 187-190.

96. Wilkinson RJ, Llewelyn M, Toozi Z, et al. Influence of vitamin $\mathrm{D}$ deficiency and vitamin $\mathrm{D}$ receptor polymorphisms on tuberculosis among Gujarati Asians in west London: a case-control study. Lancet 2000; 355: 618621.

97. Grange JM, Davies PDO, Brown RC, Woodhead JS, Kardjito T. A study of vitamin D levels in Indonesian patients with untreated pulmonary tuberculosis. Tubercle 1985; 66: 187-191.

98. Rook GAW, Steele J, Fraher L, et al. Vitamin D3, gamma-interferon, and control of proliferation of Mycobacterium tuberculosis by human monocytes. Immunology 1986; 57: 159-163.

99. Rockett KA, Brookes R, Udalove I, Vidal V, Hill AVS, Kwiatkowski D. 1, 25-dihydroxyvitamin D induces nitric oxide synthase and suppresses growth of Mycobac- 
terium tuberculosis in a human macrophage-like cell line. Infect Immun 1998; 66: 5314-5321.

100. Bellamy R, Ruwende C, Corrah T, et al. Tuberculosis and chronic hepatitis B virus infection in Africans and variation in the vitamin $\mathrm{D}$ receptor gene. $J$ Infect Dis 1999; 179: 721-724.

101. Selvaraj P, Narayanan PR, Reetha AM. Association of vitamin $\mathrm{D}$ receptor genotypes with the susceptibility to pulmonary tuberculosis in female patients and resistance in female contacts. Indian J Med Res 2000; 111: $172-179$.

102. Ottenhoff THM, Kumararatne D, Casanova J-L. Novel human immunodeficiencies reveal the essential role of type- 1 cytokines in immunity to intracellular bacteria. Immunol Today 1998; 19: 491-494.

103. Dupuis S, Doffinger R, Picard C, et al. Human interferon-gamma-mediated immunity is a genetically controlled continuous trait that determines the outcome of mycobacterial invasion. Immunol Rev 2000; 178: 129137.

104. Lammas DA, Casanova J-L, Kumararatne DS. Clinical consequences of defects in the IL-12-dependent interferon-gamma (IFN- $\gamma$ ) pathway. Clin Exp Immunol 2000; 121: 417-425.

105. Lopez-Maderuelo D, Arnalich F, Serantes R, et al. Interferon-gamma and interleukin-10 gene polymorphisms in pulmonary tuberculosis. Am J Respir Crit Care Med 2003; 167: 970-975.

106. Rossouw M, Nel NJ, Cooke GS, van Helden PD, Hoal EG. Association between tuberculosis and a polymorphic NFkappaB binding site in the interferon gamma gene. Lancet 2003; 361: 1871-1872.

107. Lio D, Marino V, Serauto A, et al. Genotype frequencies of the $+874 \mathrm{~T}>\mathrm{A}$ single nucleotide polymorphism in the first intron of the interferon-g gene in a sample of Sicilian patients affected by tuberculosis. Eur J Immunogenet 2003; 29: 371-374.

108. Fraser DA, Bulat-Kardum L, Knezevic J, et al. Interferon- $\gamma$ receptor- 1 gene polymorphism in tuberculosis patients from Croatia. Scand J Immunol 2003; 57: 480-484.

109. Newport MJ, Awomoyi AA, Blackwell JM. Polymorphism in the interferon-gamma receptor-1 gene and susceptibility to pulmonary tuberculosis in The Gambia. Scand J Immunol 2003; in press.

110. Awomoyi AA, Neientsev S, Richardson A, et al. No association between interferon-gamma receptor-1 gene polymorphism and pulmonary tuberculosis in a Gambian population sample. Thorax 2004; 59: 291-4.

111. Akahoshi M, Nakashima H, Miyake K, et al. Influence of interleukin-12 receptor $\beta 1$ polymorphisms on tuberculosis. Hum Genet 2003; 112: 237-243.

112. Wilkinson RJ, Patel P, Llewelyn M, et al. Influence of polymorphism in the genes for the interleukin (IL)-1 receptor antagonist and IL-1beta on tuberculosis. $J$ Exp Med 1999; 189: 1863-1874.

113. Hoal-van Helden EG, Epstein J, Victor TC, et al. Mannose-binding protein $\mathrm{B}$ allele confers protection against tuberculous meningitis. Pediatr Res 1999; 45: 459-464.

114. Soborg C, Madsen HO, Andersen AB, Lillebaek T, Kok-Jensen A, Garred P. Mannose-binding lectin polymorphisms in clinical tuberculosis. J Infect Dis 2003; 188: 777-782

115. Ma X, Reich RA, Wright JA, et al. Association between interleukin- 8 gene alleles and human susceptibility to tuberculosis disease. J Infect Dis 2003; 188: 349-355.

116. Li CM, Campbell SJ, Kumararatne DS, et al. Association of a polymorphism in the $\mathrm{P} 2 \mathrm{X} 7$ gene with tuberculosis in a Gambian population. J Infect Dis 2002; 186: 1458-1462.

117. Bellamy R, Ruwende C, McAdam KPWJ, et al. Mannose binding protein deficiency is not associated with malaria, hepatitis B carriage nor tuberculosis in Africans. Q J Med 1998; 91: 13-18

118. Bellamy R, Ruwende C, Corrah T. Assessment of the interleukin 1 gene cluster and other candidate gene polymorphisms in host susceptibility to tuberculosis. Tubercle Lung Dis 1998; 79: 83-89.

119. Colhoun HM, McKeigue PM, Davey Smitth G. Problems of reporting genetic association studies with complex outcomes. Lancet 2003; 361: 865-872.

120. Bellamy R, Beyers N, McAdam KPWJ, et al. Genetic susceptibility to tuberculosis in Africans: a genomewide scan. Proc Natl Acad Sci USA 2000; 97: 80058009.

121. Cervino ACL, Lakiss S, Sow O, et al. Fine mapping of a putative tuberculosis-susceptibility locus on chromosome 15q11-13 in African families. Hum Mol Genet 2002; 11: 1599-1603.

122. Risch N, Merikangas K. The future of genetic studies of complex human diseases. Science 1996; 273: 1516-1517.

123. Cordell HJ. Sample size requirements to control for stochastic variation in magnitude and location of allele sharing linkage statistics in affected sibling pairs. Ann Hum Genet 2001; 65: 491-502. 